\title{
PERSEPSI ANAK MUDA TENTANG RADIO MUSLIM Studi Kualitatif Terhadap Pendengar Radio MQ FM Yogyakarta
}

\author{
Oleh: Fatma Dian Pratiwi \\ Program Studi Ilmu Komunikasi UIN Sunan Kalijaga \\ E-mail: fatmadianpratiwi@gmail.com
}

\begin{abstract}
This research aim to describe the perception of young people about moslem radio as the media of Da'wa. Using four aspects of Da'wa as the analysis unit, i.e. 1. The Content of Al Quran and Hadits, 2. The preacher (Da'i), 3. The methods of the Da'wa and 4. The target audience.

This research uses 6 person as the object of a research. The are called "Sahabat MQ" who represent the gender, 3 males and 3 females, and also the age. 2 persons represent early youth (1923 years old), 2 persons represent middle youth (24-27 tahun), and 2 persons represent end youth (28-30 tahun).

The results are, their perception of the content of Al Quran and Hadits are very much the same in all the categories of interviewee, that they find its well broadcasted and so as the other aspects as well. This indicates that they still need da'wa radio as an alternative to listen to among other stations. And it is proven that MQ FM has been succeeding on encouraging this youngsters to do Da'wa and this is the best method to do da'wa to the youngsters.
\end{abstract}

Key words: perception, young people, moslem radio

\begin{abstract}
ABSTRAK
Penelitian ini bertujuan untuk menjabarkan dan menjelaskan persepsi anak muda tentang radio muslim sebagai media dakwah. Menggunakan 4 aspek dakwah sebagai unit analisis, yaitu 1. Isi Al Quran dan Hadits, 2. Dai 3. Metode dakwah dan 4. Target audiens

Penelitian ini menjadikan 6 orang anggota Sahabat MQ sebagai narasumber penelitian. Mewakili dari sisi gender 3 orang laki-laki dan 3 orang perempuan. Dari sisi usia, 2 orang mewakili usia muda awal (19-23 tahun), 2 orang menengah muda (24-27 tahun), dan 2 orang mewakili akhir usia muda (28-30 tahun).

Didapatkan hasil bahwa, persepsi mereka mengenai isi Al-Quran dan hadits adalah bahwa mereka disiarkan dengan bagus dan berlaku juga untuk aspek yang lain. Hal ini mengindikasikan bahwa mereka masih membutuhkan radio dakwah sebagai alternatif stasiun radio untuk didengarkan. Selain itu, MQ FM juga telah berhasil mendorong para anak muda ini untuk melakukan dakwah, dan bahwa radio dakwah dalam hal ini MQ FM menjadi metode yang tepat untuk melakukan dakwah kepada anak muda.
\end{abstract}

Kata kunci persepsi, anak muda, radio muslim

\section{A. Pendahuluan}

Radio sebagai salah satu media massa mengalami perkembangan yang luar biasa dan memiliki pendengarnya masing-masing sesuai dengan segmentasi yang dipilihnya. Dengan kata lain, di tengah perkembangan media yang begitu gencar, ternyata radio mam- 
pu menunjukkan eksistensinya sebagai media yang massive, intim, dan memiliki penetrasi tinggi.

Radio, sebagaimana fungsi media massa lainnya, akhir-akhir ini seringkali diidentikkan dengan fungsi hiburan (entertainment). Padahal, melalui radio beragam informasi juga dapat disampaikan. Salah satu bentuk informasi yang dapat disampaikan melalui radio adalah informasi tentang nilai-nilai keagamaan, pelayanan, dan perkembangan paradigma keagamaan. Berpijak pada hal tersebut, maka lahirlah fenomena penggunaan radio sebagai media untuk berdakwah. Secara khusus, ini kemudian memunculkan radio dengan segmen keluarga muslim.

Salah satu radio yang menyajikan beragam acara untuk menumbuhkan dan menyuburkan nilai-nilai keimanan Islam adalah Radio MQ FM Yogyakarta. Radio yang tersebar di sejumlah wilayah di Indonesia ini bukan sekedar lembaga bisnis, tetapi juga lembaga dakwah islamiyah.

Pendengar radio yang beragam tentunya memiliki persepsi yang berbeda tentang informasi yang menerpanya. Anak muda adalah pendengar radio yang selama ini dianggap sebagai kelompok yang paling banyak berinteraksi dalam acara radio (data pendengar MQ FM Yogyakarta, 2007). Selain itu, anak muda adalah kader perjuangan untuk menyebarluaskan nilai-nilai keislaman pada masa yang akan datang.

Radio muslim yang berusaha menyasar kelompok anak muda tentunya harus memahami apa yang menjadi insight anak muda tersebut kemudian diwujudkan dalam bentuk varian acara. Dengan demikian, kandungan acara yang berisi dakwah tersebut dapat diterima oleh pendengar. Insight tersebut telah ditangkap oleh Radio MQ FM Yogyakarta. Selanjutnya, yang menjadi hal kritikal adalah bagaimanakah persepsi dari anak muda terhadap radio muslim. Dengan mengetahui persepsi ini, maka dapat ditentukan kebijakan dalam menentukan pendekatan yang paling tepat untuk berdakwah pada anak muda melalui pemanfaatan media komunikasi massa umumnya dan radio pada khususnya.

Berdakwah memerlukan strategi yang disesuaikan dengan kondisi kekinian. Munculnya radio dengan segmen keluarga muslim merupakan fenomena penggunaan teknologi dalam aktivitas dakwah. Salah satu target dakwah yang krusial adalah kelompok anak muda. Anak muda menjadi penting karena merekalah yang nantinya diharapkan mampu menjadi kader penerus perjuangan dakwah islamiyah. Untuk itu, dalam penelitian ini akan dijawab beberapa pertanyaan terkait dengan fenomena tersebut, yaitu: Bagaimanakah persepsi anak muda tentang eksistensi radio muslim sebagai radio dakwah? Sejauh mana aktivitas mendengarkan radio muslim mampu menginspirasi anak muda untuk berdakwah? Pendekatan seperti apakah yang dapat digunakan untuk menyampaikan informasi keagamaan (dakwah) terhadap kelompok anak muda?

Tujuan penelitian sejalan dengan perumusan masalah di atas, penelitian ini bertujuan untuk: Mengetahui persepsi anak muda tentang eksistensi radio muslim sebagai radio dakwah. Mencari tahu sejauh manakah aktivitas mendengarkan radio muslim mampu menginspirasi anak muda untuk berdakwah. Merumuskan pendekatan yang dapat digunakan untuk menyampaikan informasi keagamaan terhadap kelompok anak muda.

Signifikansi praktis penelitian ini dapat bermanfaat bagi pemerintah, dalam hal ini adalah Kementrian Agama sebagai lembaga terkait, untuk merumuskan strategi yang tepat guna melakukan diseminasi nilai-nilai keagamaan kepada kelompok anak muda melalui 
Diterbitkan oleh Program Studi Ilmu Komunikasi

Universitas Ahmad Dahlan Yogyakarta

media radio. Secara umum, penelitian ini juga dapat menjadi insight bagi Kementrian Agama untuk mengetahui bagaimana respon anak muda terhadap perkembangan penyiaran nilai-nilai keagamaan yang telah dilakukan selama ini.

Penelitian ini juga bermanfaat bagi lembaga radio muslim sebagai pertimbangan dalam penetapan kebijakan yang berkait dengan kandungan dan waktu siaran acara yang menyasar anak muda.

Signifikansi teoritis dengan adanya penelitian ini diharapkan dapat memperkaya kajian komunikasi yang memokuskan pada pembahasan tentang penggunaan radio (penyiaran) sebagai media dakwah. Bagi peneliti, penelitian akan bermanfaat bagi penyempurnaan bahan pengajaran dan diskusi pada mata kuliah Komunikasi Lintas Agama dan Budaya

\section{B. KERANGKA TEORI}

\section{Pengertian Persepsi}

Persepsi menurut Kamus Besar Bahasa Indonesia (KBBI) adalah tanggapan (penerimaan) langsung dari sesuatu; serapan serta proses seseorang mengetahui bebrapa hal melalui pancaindranya (kbbi.web.id/persepsi).

Menurut Sugihartono, dkk (2007:8) mengemukakan bahwa persepsi adalah kemampuan otak dalam menerjemahkan stimulus atau proses untuk menerjemahkan stimulus yang masuk ke dalam alat indera manusia. Dalam persepsi terdapat perbedaan sudut pandang berkaitan dengan perbedaan kemampuan penginderaan. Oleh karena itu Bimo Walgito (2004:70) mengungkapkan bahwa persepsi merupakan suatu proses pengorganisasian, penginterpretasian terhadap stimulus yang diterima oleh organisme atau individu sehingga menjadi sesuatu yang berarti, dan merupakan aktivitas yang integrated dalam diri individu. Respon sebagai akibat dari persepsi dapat diambil oleh individu dengan berbagai macam bentuk.

Stimulus mana yang akan mendapatkan respon dari individu tergantung pada perhatian individu yang bersangkutan. Berdasarkan hal tersebut, perasaan, kemampuan berfikir, pengalaman-pengalaman yang dimiliki individu tidak sama, maka dalam mempersepsi suatu stimulus, hasil persepsi mungkin akan berbeda antar individu dengan individu lain.

Sehingga persepsi juga dapat didefinisikan sebagai pengamatan tentang objek, peristiwa atau hubungan-hubungan yang diperoleh dengan menyimpulkan informasi dan menafsirkan pesan (Rakhmat, 2007:51). Sedangkan, Suharman (2005:23) menyatakan : "persepsi merupakan suatu proses menginterpretasikan atau menafsir informasi yang diperoleh melalui sistem alat indera manusia : "Menurutnya ada tiga aspek di dalam persepsi yang dianggap relevan dengan kognisi manusia, yaitu pencatatan indera, pengenalan pola dan perhatian.

\section{Proses Persepsi}

Menurut Miftah Toha (2003:145), proses terbentuknys persepsi didasari pada beberapa tahapan, yaitu: 
2.1 Stimulus atau rangsangan

Terjadinya persepsi diawali ketika seseorang dihadapkan pada suatu stimulus/rangsangan yang hadir dari lingkungannya

2.2 Registrasi

Dalam proses registrasi, suatu gejolak yang nampak adalah mekanisme fisik yang berupa penginderaan dan syarat seseorang berpengaruh melalui alat indera yang dimilikinya. Seseorang dapat mendengarkan atau melihat informasi yang terkirim kepadanya, kemudian mendaftar semua informasi yang terkirim kepadanya tersebut

2.3 Interpretasi

Interpretasi merupakan suatu aspek kognitif dari persepsi yang sangat penting yaitu proses memberikan arti kepada stimulus yang diterimanya. Proses interpretasi tersebut bergantung pada cara pendalaman, motivasi, dan kepribadian seseorang

\section{Radio}

Radio adalah teknologi yang digunakan untuk pengiriman sinyal dengan cara modulasi dan radiasi elektromagnetik. Gelombang ini melintas dan merambat melewati ruang angkasa yang hampa udara, karena gelombang ini tidak memerlukan medium pengangkut (seperti molekul udara).

Pada awalnya, penggunaan radio adalah maritim, untuk mengirimkaan pesan telegraf menggunakan kode Morse antara kapal dan darat. Salah satu pengguna awal termasuk Angkatan Laut Jepang memata-matai armada Rusia pada saat Perang Tsushima pada tahun 1901.

Sementara di Indonesia, stasiun radio Bataviase Radio Vereeniging (BRV) menjadi siaran pertama radio di Indonesia yang resmi berdiri pada 16 Juni 1925. Masyarakat Indonesia berinisiatif mendirikan stasiun radio yang berawal dari pendirianSolosche Radio Vereeniging (SRV) di Solo pada 1934.

Pada perkembangannya, keberadaan radio semakin tergerus oleh hadirnya media audio visual maupun media baru berbasis internet. Berdasarkan survey Nielsen 2014, tiap tahun pendengar radio mengalami penurunan hingga $3 \%$. Secara keseluruhan, konsumsi media di kota Jawa maupun luar Jawa $95 \%$ menunjukkan televisi menjadi media utama yang dikonsumsi masyarakat Indonesia, yang disusul 3\% oleh internet, radio $20 \%$, surat kabar 12\%, tabloid 6\% dan majalah 5\% (http://komunikasi.us/index.php/course/2953-perkembangan-radio-pada-zaman modern)

Untuk itu, agar dapat bertahan radio kemudian merubah bentuk yang konvensional menjadi radio bersegmentasi. Hingga saat ini berkembang dengan adanya fenomena radio muslim. Keberadaan radio muslim ini merupakan jawaban dari besarnya audiens yang menginginkan radio bukan hanya menyajikan informasi, tetapi juga radio yang dapat memberikan inspirasi dan menambah rasa keimanan.

MQ FM Yogyakarta memosisikan dirinya sebagai radio keluarga muslim memberikan kesempatan kepada audiens untuk memilih media mana yang diinginkannya. Ini sesuai dengan uses and gratification theory yang menyebutkan bahwa audiens melakukan pembedaan dalam menggunakan media sehingga mereka memilih dan aktif dalam memenuhi kebutuhannya melalui media (Littlejohn, 2005:266). Dalam dependency theory disebutkan, sejalur dengan teori sebelumnya, bahwa terjadi ketegantungan antara media, au- 
Diterbitkan oleh Program Studi IImu Komunikasi

Universitas Ahmad Dahlan Yogyakarta

diens, dan sistem sosial yang ada. (Littlejohn, 2005:167). Dengan lain kata dapat disimpulkan bahwa audiens secara bertanggung jawab memilih pesan dan jenis informasi yang dibutuhkannya melalui media yang relevan dengan dipengaruhi sistem sosial dimana dirinya berada.

\section{Dakwah}

Salah satu pesan yang ingin disampaikan MQ FM sebagai radio muslim adalah penggunaan media ini sebagai media dakwah. Dakwah berasal dari kata dalam bahasa Arab $d a$ 'a. Kata ini memiliki sejumlah arti, tetapi yang paling banyak digunakan untuk mendefinisikan dakwah adalah memanggil atau mengundang (Kasman, 2004:114). Muhammad Al Ghazali yang dikutip oleh Kasmani, dkk dalam risetnya yang berjudul "Dakwah Content and Its Methode: an Analysis on Islamic Websites" mendefinisikan dakwah sebagai program lengkap yang mengandung semua pengetahuan yang diperlukan oleh manusia untuk menuju jalan kehidupan yang layak. Dr. Yusuf Al Qardawi merujuk dakwah sebagai sebuah upaya mengajak orang lain ke Islam, berserah diri kepada Allah, dan tidak mengikatkan diri kepada kepercayaan lainnya. Osman Chuah Abdullah membagi dakwah menjadi empat komponen. Komponen dakwah yang pertama adalah isi Al Quran dan Hadits. Di dalam islam, Al Quran dijadikan sebagai sumber pengetahuan yang utama dan orisinal dimana isinya dilindungi dan tidak mengalami perubahan (Nor Shahriza and Norzelatun, 2005 dalam Kasmani, dkk). Hadits merujuk pada sejumlah perkataan, perbuatan, persetujuan, gambaran fisik dan moral yang dilekatkan kepada Nabi Muhammad.

Komponen dakwah yang kedua adalah penceramah atau da'i. Di dalam Islam, tugas mengajak orang lain adalah kewajiban setiap orang. Akan tetapi, keberhasilan dakwah bergantung pada potensi dan kapasitas seseorang (Markazi Maktaba Islami, 1983:12 dalam Kasmani, dkk). Oleh karenanya, dakwah memerlukan pengomunikasian pesan yang disampaikan oleh komunikator yang tidak hanya menguasai isi Al Quran dan Hadits, tetapi juga ilmu pengetahuan lainnya.

Komponen ketiga dakwah adalah metode dalam penyampaiannya. Ini merujuk pada cara dan makna yang disampaikan. Metode penyampaian ini pun selalu dilekatkan kepada contoh metode berdakwah yang diberikan Nabi Muhammad, yakni hikmah, nasihat, dan debat. Hikmah merujuk pada intonasi dan isi dalam berdakwah dengan mempertimbangkan waktu, tempat, dan kandungan yang tepat kepada orang yang tepat (Markazi Maktaba Islami, 1983: 12, Osman, 2005:40 dalam Kasmani, dkk). Nasihat merujuk pada penyebaran kata-kata dan perbuatan baik, sedangkan debat bearti upaya menjelaskan dan menghadapi situasi yang mengganggu nilai-nilai keimanan (Ghazali Darulsalam, 1996:12 dalam Kasmani, dkk).

Komponen keempat dakwah adalah target audiens. Target audiens ini mempertimbangkan siapakah yang akan menjadi target dari penyampaian pesan dalam aktivitas dakwah tersebut. Identifikasi target audiens ini akan mempengaruhi pesan dan metode yang digunakan dalam proses komunikasi. Sejumlah konten dakwah inilah yang nantinya dijadikan sebagai indikator untuk menganalisis isi pesan radio muslim sebagai media dakwah.

Anak muda sebagai kelompok usia produktif menjadi krusial ketika dikaitkan dengan dakwah mengingat mereka adalah calon pemimpin di masa datang. Artinya, mereka adalah penerus dari tongkat estafet dakwah. Akibat terpaan pesan dari media massa -radio- 
individu dapat mengalami perubahan sikap dan persepsinya tentang suatu objek. Salah satu teori yang menjelaskan tentang dampak dari konsumsi media adalah cultivation theory yang dipelopori oleh Gerbner dalam risetnya tentang dampak televisi terhadap perubahan sikap dan persepsi individu (Littlejohn, 2005:288).

Persepsi terhadap isi radio muslim sebagai radio dakwah dapat beragam pada pendengarnya. Milton Rokeach menyebutkan teori tentang Kepercayaan, Sikap, dan Nilai-nilai (Theory of Beliefs, Attitudes, and Values). Rokeach percaya bahwa setiap individu mengorganisasi keyakinan, sikap, dan nilai-nilai sebagai pemandu dalam perilakunya. Keyakinan adalah ratusan dari ribuan pernyataan yang kita susun mengenai diri sendiri dan dunia luar (Littlejohn, 2005:79, 1999:139). Sikap adalah kelompok keyakinan yang teorganisasikan pada suatu objek dan memberikan kecenderungan kepada seseorang terhadap suatu objek. Nilai adalah tipe khusus dari keyakinan sebagai pusat dari sistem dan berperan sebagai panduan hidup.

Dari teori tersebut, individu mempersepsikan suatu objek tidak semata-mata karena keberadaan objek tersebut, melainkan dipengaruhi oleh sejumlah keyakinan yang dimilikinya. Salah satu bentuk keyakinan yang banyak mempengaruhi cara individu bersikap adalah agama. Secara etimologis, agama berasal dari bahasa Sansekerta " $a$ " yang bearti "tidak" dan "gama" yang artinya "kacau". Dari kedua kata ini, agama mengandung pengertian sebagai suatu peraturan yang mengatur kehidupan manusia agar tidak kacau. Agama secara sosiologis adalah gejala sosial yang umum dan dimiliki oleh seluruh masyarakat yang ada di dunia ini tanpa kecuali. Berdasarkan pengkajian para sosiolog, agama merupakan suatu pandangan hidup yang harus diterapkan dalam kehidupan individu maupun kelompok. Keduanya mempunyai hubungan yang saling mempengaruhi dan bergantung (interdependence) dengan semua faktor yang yang ikut membentuk struktur social di masyarakat mana pun (Kahmad, 2002: 13-15). Oleh karenanya, agama juga merupakan salah satu kategori pandangan dunia. Di dalam agama lazimnya terdapat ajaran mengenai bagaimana seharusnya manusia berhubungan dengan dirinya sendiri, orang lain, tanah, alam semesta, dan Zat yang menciptakannya. Setiap agama memiliki ajaran yang khas tentang bagaimana tata cara berhubungan manusia satu dengan lainnya (Mulyana, 2005:35).

Dengan demikian dapat dikatakan bahwa agama sebagai sebuah sistem yang berisikan nilai-nilai sebagai panduan hidup individu mempengaruhi penilaian atau pun kecenderungan sikap individu terhadap fenomena sosial atau pun objek di luar dirinya. Agama juga menjadi sumber dari sistem nilai yang dimiliki individu. Ketika individu telah mencerap nilai-nilai dari lingkunganya maka nilai-nilai itu akan menjadi standar atau kriteria untuk memandu tindakan, mengembangkan sikap terhadap objek dan situasi yang relevan, menilai sikap dan tindakan diri sendiri maupun orang lain. Samovar dan Porter mengatakan bahwa nilai bersifat normatif karena menetapkan apa yang baik dan buruk, benar atau salah, layak atau tidak layak, bermanfaat atau sia-sia, tentang hubungan individu dengan diri sendiri, orang lain, masyarakat, alam dan Tuhan (Mulyana, 2003: 44).

Agama dalam perspektif sosiopsikologi merupakan faktor-faktor dalam diri individu yang dapat mempengaruhi cara pandangnya terhadap suatu objek. Saat merespon sebuah objek, individu tidak hanya dipengaruhi oleh faktor di dalam dirinya, melainkan juga faktor dari luar dirinya. Salah satu faktor ini adalah terpaan informasi melalui film sebagai media komunikasi massa. Menonton film diasumsikan mempengaruhi pendapat atau pun panda- 
Diterbitkan oleh Program Studi IImu Komunikasi

Universitas Ahmad Dahlan Yogyakarta

ngan individu terhadap suatu objek. Bahkan dapat dikatakan bahwa melalui media film dapat dilakukan transmisi nilai-nilai atau fungsi sosialisasi. Sosialisasi merujuk pada bagaimana indiividu mengadopsi perilaku dan nilai-nilai dari suatu kelompok. Media massa memotret masyarakat, dan dengan menonton, mendengar, dan membaca individu belajar bagaimana seharusnya bertindak dan menentukan nilai-nilai apa yang dianggap penting (Dominick, 2007:37). Film sebagai media massa juga dapat berperan penting dalam transmisi sikap, persepsi, dan kepercayaan dalam diri individu (Dominick, 2007: 417).

Media mampu memberikan dampak afektif dimana audiens dapat turut merasakan iba, sedih, terharu, gembira, dan lain sebagainya. Bahkan, media juga mampu memberikan efek membangkitkan rangsang untuk melakukan perilaku, tindakan, atau kegiatan tertentu (Ardianto \& Erdinaya, 2005: 54-55). Media mampu membentuk pengetahuan, persepsi, dan sikap individu. Pernyataan ini juga diperkuat oleh stimulation theory yang menyebutkan bahwa menonton adegan dalam media dapat menstimulus individu untuk bertindak seperti apa yang ditontonnya. Penelitian yang dilakukan oleh psikolog Leonard Berkowitz dan koleganya di Universitas Wisconsin membuktikan teori tersebut (Dominick, 2007: 429). Ini juga berbanding lurus dengan social learning theory yang dikemukan oleh Albert Bandura (Saverin \& Tankard, 2001:276, Wartella, et.al, 2002:401). Menurut teori ini, banyak sekali dampak dari media yang terjadi melalui proses pembelajaran sosial melalui pengamatan dan pengalaman yang dimiliki individu.

\section{METODE PENELITIAN}

Penelitian ini menggunakan konstruktivisme sebagai paradigma penelitian. Pendekatan ini mengemukakan gagasan bahwa realitas yang kita tinggali ini terbentuk dari waktu ke waktu melalui proses komunikasi, interaksi kita dengan orang-orang di sekitar, dan sejarah kita bersama. Realitas oleh karena itu merupakan merupakan hal yang dimiliki bersama dan diterima sebagaimana cara dunia diterima dan dipersepsi (Locke dalam Daymon \& Holloway, 2008:6). Tipe penelitian adalah deskriptif dengan menggunakan metode penelitian kualitatif. Pendekatan yang digunakan adalah pendekatan fenomenologi. Fenomenologi adalah studi tentang pengetahuan yang timbul dari kesadaran. Dengan kata lain, cara seseorang memahami suatu objek atau kejadian adalah dengan mengalaminya secara sadar. Fenomena sendiri adalah suatu penampakan atau kehadiran dari suatu objek, kejadian, atau kondisi dalam persepsi suatu individu. Jadi, apa yang timbul dalam kesadaran adalah suatu fenomena dan realitas dalam fenomenologi adalah cara dari suatu hal yang timbul dalam kesadaran persepsi individu (Littlejohn, 1999:199). Hegel menyatakan bahwa fenomenologi mengacu pada pengetahuan sebagaimana pengetahuan itu timbul dalam kesadaran, ilmu yang menggambarkan apa yang diterima, dirasakan, dan diketahui seseorang dalam kesadaran dan pengalaman (Moustakas, 1994:26).

\section{Unit Analisis Data}

Penelitian ini menggunakan unit analisis data berupa pendengar radio MQ FM Yogyakarta sebagai representasi dari radio muslim dengan rentang usia 19-30 tahun. Rentang usia tersebut dipilih karena menunjukkan wilayah usia untuk kategori anak muda awal (19-23 tahun), tengah (24-27 tahun), dan akhir (28-30 tahun). Ini sesuai dengan tema dan 
judul penelitian. Jumlah narasumber adalah 6 (enam) orang dengan pembagian 3 orang laki-laki dan 3 orang perempuan. Penentuan jenis kelamin ini diperlukan untuk mendapatkan persepsi dari masing-masing peran gender yang ada.

\section{Jenis data penelitian}

a) Data primer

Data primer merupakan data yang diperoleh secara langsung dari objek/subjek penelitian perorangan, kelompok, dan organisasi (Ruslan, 2003:29). Dalam penelitian ini, data primer adalah data yang diperoleh dari wawancara mendalam dengan narasumber penelitian.

b) Data sekunder

Data sekunder merupakan data dalam bentuk sudah jadi (tersedia) melalui publickasi dan informasi yang dikeluarkan di berbagai organisasi termasuk majalah, jurnal, dan literature lain yang relevan. (Ruslan, 2003:29)

c) Metode Pengumpulan Data

Pengumpulan data akan dilakukan dengan beberapa metode, yakni:

d) Wawancara

Wawancara mendalam akan digunakan untuk mendapatkan pengalaman dan kesadaran narasumber tentang radio muslim. Wawancara adalah percakapan dengan maksud tertentu (Moleong, 2001:135). Dengan wawancara, data dikumpulkan melalui tanya jawab secara mendalam (indept interview) dan langsung kepada narasumber. Narasumber yaitu orang yang dimanfaatkan untuk memberikan informasi tentang situasi dan latar penelitian (Moleong, 2001:90).

e) Studi pustaka

Studi pustaka dilakukan untuk mendapatkan data sekunder yang relevan dengan penelitian untuk merefleksikan sejumlah hasil temuan penelitian.

\section{Analisis Data}

Dalam penelitian ini digunakan modifikasi metode analisis data fenomenologi dari

Van Kaam (Moustakas, 1994:121-122) meliputi:

a. Listing and Preliminary Grouping, yaitu membuat daftar setiap ekspresi yang relevan dengan pengalaman. Dalam hal ini membuat daftar jawaban narasumber dari semua hasil wawancara.

b. Reduction and Elimination. Tahap ini dilakukan untuk mendapatkan invariant constituen yang merupakan data utama yang akan dianalisis pada tahap selanjutnya. Untuk mendapatkannya kita dapat menguji setiap ekspresi (hasil wawancara) dengan dua persyaratan:

a) Apakah ekspresi tersebut mengandung momen pengalaman yang penting dan mengandung unsur pokok yang cukup baik untuk memahami fenomena?

b) Apakah ekspresi tersebut memungkinkan untuk dikelompokkan dalam suatu kelompok besar dan diberi label?

c) Adapun ekspresi yang tidak memunuhi kedua syarat, muncul berulang ulang, overlapping, dan tidak jelas dapat dihilangkan.

c. Clustering and Thematizing the Invariant Constituents, mengelompokkan unsur pokok pengalaman yang berhubungan ke dalam label tematik. Pengelompokkan dan pelabelan unsur pokok merupakan tema inti dari pengalaman. 
Diterbitkan oleh Program Studi Ilmu Komunikasi

Universitas Ahmad Dahlan Yogyakarta

d. Final Identification of the Invariant Constituents and Themes by Appication Validation. Merupakan proses memvalidkan invariant constituent dengan tema yang menyertainya terhadap rekaman utuh pernyataan narasumber.

a) Apakah diungkapkan secara eksplisit dalam transcript yang utuh?

b) Apakah cocok dengan konteks dalam transcript jika pernyataan tersebut tidak diekspresikan secara eksplisit?

c) Apabila tidak sesuai dan tidak dinyatakan secara ekspilisit maka pernyataan tersebut harus dihapus.

e. Menggunakan tema dan invariant constituents yang valid untuk menyusun gambaran tekstural individu (Individual Textural Description) tentang pengalaman

f. Menyusun untuk setiap peneliti gambaran structural individual (Individual Stuctural Description) tentang pengalaman-pengalaman berdasar variasi imaginatif dan deskripsi tekstural individu (Individual Textural Description and Imaginative Variation)

g. Menyusun untuk masing-masing peserta penelitian sebuah gambaran struktural tekstural tentang makna dan esensi pengalaman, memadukan unsur pokok dan tema yang berbeda.

\section{PEMBAHASAN}

Dalam penelitian ini, pembahasan akan difokuskan pada persepsi enam 6 anak muda terhadap 4 aspek dakwah yaitu: Komponen dakwah yang pertama adalah isi Al Quran dan Hadits. Di dalam islam, Al Quran dijadikan sebagai sumber pengetahuan yang utama dan orisinal dimana isinya dilindungi dan tidak mengalami perubahan (Nor Shahriza and Norzelatun, 2005 dalam Kasmani, dkk). Hadits merujuk pada sejumlah perkataan, perbuatan, persetujuan, gambaran fisik dan moral yang dilekatkan kepada Nabi Muhammad.

Komponen dakwah yang kedua adalah penceramah atau da'i. Di dalam Islam, tugas mengajak orang lain adalah kewajiban setiap orang. Akan tetapi, keberhasilan dakwah bergantung pada potensi dan kapasitas seseorang (Markazi Maktaba Islami, 1983:12 dalam Kasmani, dkk). Oleh karenanya, dakwah memerlukan pengomunikasian pesan yang disampaikan oleh komunikator yang tidak hanya menguasai isi Al Quran dan Hadits, tetapi juga ilmu pengetahuan lainnya.

Komponen ketiga dakwah adalah metode dalam penyampaiannya. Ini merujuk pada cara dan makna yang disampaikan. Metode penyampaian ini pun selalu dilekatkan kepada contoh metode berdakwah yang diberikan Nabi Muhammad, yakni hikmah, nasihat, dan debat. Hikmah merujuk pada intonasi dan isi dalam berdakwah dengan mempertimbangkan waktu, tempat, dan kandungan yang tepat kepada orang yang tepat (Markazi Maktaba Islami, 1983: 12, Osman, 2005:40 dalam Kasmani, dkk). Nasihat merujuk pada penyebaran kata-kata dan perbuatan baik, sedangkan debat bearti upaya menjelaskan dan menghadapi situasi yang mengganggu nilai-nilai keimanan (Ghazali Darulsalam, 1996:12 dalam Kasmani, dkk).

Komponen keempat dakwah adalah target audiens. Target audiens ini mempertimbangkan siapakah yang akan menjadi target dari penyampaian pesan dalam aktivitas dak- 
wah tersebut. Identifikasi target audiens ini akan mempengaruhi pesan dan metode yang digunakan dalam proses komunikasi. Sejumlah konten dakwah inilah yang nantinya dijadikan sebagai indikator untuk menganalisis isi pesan radio muslim sebagai media dakwah.

Enam pendengar MQ FM yang peneliti jadikan narasumber, adalah anggota dari keluarga off air MQ FM. Mereka dipanggil dengan sebutan sahabat. Nama-nama mereka yaitu, sahabat Yogi, dahabat Fauzi dan sahabat Fito adalah nama narasumber ikhwan (lakilaki). Sedangkan untuk yang akhwat (perempuan) yaitu sahabat Ida, sahabat Nur dan sahabat Ika. Dengan rentang usia 19-30 tahun. Rentang usia tersebut dipilih karena menunjukkan wilayah usia untuk kategori anak muda awal (19-23 tahun), tengah (24-27 tahun), dan akhir (28-30 tahun). Ini sesuai dengan tema dan judul penelitian. Jumlah narasumber adalah 6 (enam) orang dengan pembagian 3 orang laki-laki dan 3 orang perempuan. Penentuan jenis kelamin ini diperlukan untuk mendapatkan persepsi dari masing-masing peran gender yang ada.

Menggunakan metode pengambilan data Focus Group Discussion dan via surel, peneliti dibantu oleh para mahasiswa yang menjadi asisten penelitian. Pambahasan akan dituliskan per komponen.

\section{Isi Al Qur'an dan Hadits}

Peneliti mewawancara narasumber. 3 narasumber akhwat (perempuan, pen) dan ikhwan (laki-laki, pen). Dari hasil wawancara dengan 3 narasumber akhwat yaitu sahabat Ida, sahabat Nur dan sahabat Ika didapatkan data bahwa radio MQ FM telah menyiarkan isi Al Quran dan hadits secara bagus dan mengena. Mereka terutama terkesan dengan penyampaian isi Hadits yang meliputi tuntunan hidup sehari-hari dan penyiaran yang diulang. Membuat pendengar yang sebelumnya terlewat dapat mendengarkan. Misalnya ajakan untuk bersedekah, adab minum harus duduk dan isi hadits yang berkaitan dengan fiqih, muamalah dan lain-lain.

Sementara untuk penyampaian isi Al Qur'an, ketiganya menyatakan bahwa MQ FM menyiarkan potongan-potongan ayat lengkap dengan terjemahnya. Ini menguntungkan untuk para pendengar yang hanya mendengarkan sambil lalu tidak dengan nitat untuk menyimak secara utuh.

Untuk yang ingin menyimak dengan seksama, menurut narasumber dapat mendengarkan acara "Maghrib Mengaji", tujuannya adalah untuk para pendengar yang ingin lebih melancarkan bacaan Al Qur'annya. Menurut para narasumber, dengan sering mendengarkan maka akan cepat bisa. Materinya meliputi, Qiro'ah, Iqro', Tajwid dan lain-lain.

Untuk para sahabat ikhwan, mereka menjawab dengan lebih singkat akan tetapi dengan persepsi yang sama. Menurut mereka, untuk isi Al Qur'an dan hadits sudah disampaikan dengan baik dan benar.

\section{Penceramah / Da'i}

Untuk penceramah atau da'i, para narasumber memiliki persepsi bahwa MQ FM memilih para penceramahnya dengan tidak mendasarkan pada satu kelompok atau golongan tertentu. Seperti kata sahabat Ida "para penceramah di pilih berdasarkan kompetensi yang dimiliki. Misalnya dari masjid Syuhada atau bahkan dari kalangan pengusaha seperti Ust. Awan Abdullah seorang pengusaha rental motor dan mobil, dan kembarannya Ust. 
Diterbitkan oleh Program Studi Ilmu Komunikasi

Universitas Ahmad Dahlan Yogyakarta

Adi Abdillah, seorang pengusaha properti" (dikutip dari hasil wawancara yang dilakukan pada hari Sabtu, 20 Februari 2016). Sementara sahabat Ika mengatakan ada juga da'i yang memiliki pendekatan dakwah melalui kosmetik lebih spesifik lagi, kosmetika herbal.

Sementara dari para sahabat ikhwan, mereka memiliki persepsi bahwa MQ FM telah memilih secara tepat da' $i$-da'i yang menjadi narasumber dakwah radio tersebut. Seperti dikutip dari sahabat Fito, "MQ FM memilih da'i- da'i yang telah dikenal oleh masyarakat umum, sehingga pendengar seperti telah memiliki kedekatan dengan da' $i$-da' $i$ tersebut, sehingga penyampaian dakwah akan lebih maksimal" (dikutip dari wawancara yang dilakukan pada hari Sabtu, 20 Februari 2016).

\section{Metode Penyampaian}

Mengenai metode penyampaian, para sahabat MQ FM yang menjadi nara sumber penelitian ini memiliki persepsi bahwa, metode penyampaian yang dilakukan oleh MQ FM sangat bervariasi didasarkan pada materi dakwah dan tujuan yang dicapai. Sehingga pendengar dapat memahami materi dakwah yang disampaikan. Misalnya seperti yang disampaikan sahabat Nur, "setiap jam 22.00-23.00 ada satu rubrik yang bernama "Tema Kehidupan", isinya adalah para pendengar yang memiliki masalah dapat menyampaikan ke radio, nanti akan diberikan solusi oleh pendengar yang lain. Fungsi penyiar adalah sebagai semacam moderator". Menurut para narasumber, mekanisme seperti ini sangat mengena karena si penyampai adalah teman-teman sesama pendengar sendiri, bukan hanya da'i. Sebagai pemancing adalah adanya permintaan untuk memutar lagu, di MQ lagu yang diperdengarkan disingkat "MuPos", musik positif yaitu genre musik-musik Islami atau yang sering disebut dengan nasyid.. Para pendengar yang menginginkan lagunya diputar harus memberikan pendapat terlebih dahulu. Ketika ada perbedaan pendapat yang cukup runcing, maka tugas ustadz untuk memberikan solusi. Dan nanti disimpulkan oleh penyiar.

\section{Target Audiens}

Untuk target audiens, para narasumber memiliki persepsi bahwa MQ FM memiliki target audiens yang lengkap didasarkan pada usia. Dan peyiarannya disesuaikan dengan waktu. Misalnya, jam 6 - 7 MQ FM merelay dari Bandung (MQ pusat) berita. Hal ini didasarkan pada, setiap jam 6-7 target audiensnya adalah orang-orang dewasa yang membutuhkan berita dan informasi terkini. Untuk jam rehat (istirahat), anak-anak SMP dan SMA sekitar jam 13.00 - 15.00, didasarkan pada bahwa pada jam ini mereka telah pulang dari sekolah. Sedangkan untuk anak-anak, MQ memberi waktu khusus setiap hari minggu dari pagi hingga sore.

Dari data diatas, para narasumber memiliki persepsi yang sama bahwa, radio MQ FM dilihat dari dari 4 indikator dakwah, yaitu isi Al Quran dan hadits, penceramah/da'i, metode penyampaian dan target audiens, telah memenuhi syarat disebut sebagai radio dakwah. Jika dianalisis menggunakan teori uses and gratification, yang menyebutkan bahwa audiens melakukan pembedaan dalam menggunakan media sehingga mereka memilih dan aktif dalam memenuhi kebutuhannya melalui media (Littlejohn, 2005:266). Para narasumber terutama akhwat, menghidupkan radio dan mendengarkan MQ FM setiap hari dan tidak pernah dimatikan dari pagi hingga malam, menemani mereka beraktivitas. Dari aktivitas mendengarkan ini, mereka merasa mendapatkan ilmu yang bermanfaat tidak hanya ilmu 
akhirat (bahasa narasumber, pen) tetapi juga ilmu dunia. Semacam tips-tips untuk melakukan aktivitas sehari-hari, resep masakan, mencuci pamencuci pakia

mencuci pakaian, membersihkan rumah hingga jual beli barang bekas. Para nara sumber perempuan bahkan mengakui bahwa dia menjadi muslimah yang lebih bak sejak sering mendengarkan MQ FM. Untuk seseorang yang hanya mengetahui Islam dari nol, mereka merasa terbantu dengan cara mendengarkan MQ FM, menambah pengetahuan mereka akan agama mereka. Begitu pula dengan narasumber ikhwan. Mereka juga mengaku menjadi muslim yang lebih baik setelah mendengarkan MQ FM secara lebih intensif. Ini sejalan pula dengan teori bahwa media massa memotret masyarakat, dan dengan menonton, mendengar, dan membaca individu belajar bagaimana seharusnya bertindak dan menentukan nilai-nilai apa yang dianggap penting (Dominick, 2007:37).

Mereka memiliki kebutuhan untuk meningkatkan pengetahuan agama, sehingga mereka memilih untuk mendengarkan MQ FM karena dalam persepsi mereka radio MQ FM sebagai salah satu media massa yang ada, dapat memenuhi kebutuhan tersebut. Ini sejalan dengan teori bahwa media mampu memberikan dampak afektif dimana audiens dapat turut merasakan iba, sedih, terharu, gembira, dan lain sebagainya. Bahkan, media juga mampu memberikan efek membangkitkan rangsang untuk melakukan perilaku, tindakan, atau kegiatan tertentu (Ardianto \& Erdinaya, 2005: 54-55). Media mampu membentuk pengetahuan, persepsi, dan sikap individu. Ini juga berbanding lurus dengan social learning theory yang dikemukan oleh Albert Bandura (Saverin \& Tankard, 2001:276, Wartella, et.al, 2002:401). Menurut teori ini, banyak sekali dampak dari media yang terjadi melalui proses pembelajaran sosial melalui pengamatan dan pengalaman yang dimiliki individu.

Menurut Siantari Rihartono, seorang pengajar mata kuliah Komunikasi Massa pada program studi Ilmu Komunikasi, UIN Sunan Kalijaga, sekaligus pengamat media massa, memberikan pendapatnya seputar keberadaan radio dakwah ini. Menurutnya keberadaan radio dakwah sangat dibutuhkan untuk memenuhi kebutuhan masyarakat akan pengetahuan agama, akan tetapi ada hal-hal yang harus diperhatikan oleh para pemilik radio ini terutama jam siaran dan segmentasi audiens. Terutama berkitan dengan siaran radio dakwah agar tidak saling memblok satu sama lain. Misalnya radio dakwah kristen dan Islam, harus saling menghormati sehingga dapat menyajikan siarannya seiring dan sejalan tidak saling mengganggu. "Saya pernah mendengarkan siaran salah satu radio kristen yang menyiarkan diaran agamanya saat seharusnya acara anak-anak diperdengarkan. Begitu pula di radio Islam, pernah melakukan hal tersebut. Akan lebih baik jika masing-masing radio memperhatikan segmentasi audiens dan jam-jam yang tepat untuk mereka" (berdasarkan wawancara yang dilakukan pada hari Kamis, 25 Februari 2016).

Selain itu, tambahnya, "sebaiknya stasiun-stasiun radio dakwah ini juga mengadakan semacam kegiatan off air, sehingga dakwah yang disampaikan dapat lebih efektif karena langsung dapat dilakukan tanpa ada perantaraan media massa"( Ibid). Ini sejalan dengan apa yang dikemukakan oleh nara sumber yang mengatakan, kegiatan off air yang diselenggarakan oleh MQ FM menjadi salah satu kegiatan yang dinantikan oleh para anggota sahabat MQ ( sebutan untuk para pendengar MQ FM). Akan tetapi, ada satu hal yang menjadi kekecewaan mereka yaitu, kurangnya antusiasme para penyiar MQ FM menghadiri kegiatan ini. "sangat sedih ketika kami telah menyiapkan segala hal untuk pertemuan ini, akan tetapi para penyiar tidak menunjukkan antusiasme dengan datang terlambat bahkan 
Diterbitkan oleh Program Studi llmu Komunikasi

Universitas Ahmad Dahlan Yogyakarta

tidak datang sama sekali" (berdasarkan wawancara dengan para narasumber pada hari Sabtu, 20 Februari 2016). Akan tetapi sangat lain ceritanya ketika tujuan pertemuan off air adalah untuk sekedar makan-makan atau melakukan perjalanan ke tempat wisata, biasanya para penyiar akan lebih antusias. Para nara sumber memiliki persepsi bahwa mungkin para penyiar sudah merasa cukup dengan kegiatan dakwah sehari-hari sehingga mereka lebih tertarik ketika tujuan berkumpul adalah untuk sekedar berbincang-bincang hal yang ringan dan makan-makan.

\section{E. KESIMPULAN}

Radio, sebagai salah satu bentuk media massa memiliki fungsi memberikan informasi yang dalam penelitian ini dikhususkan menjadi informasi dakwah keagamaan Islam. Bahwa setelah dilakukan penelitian ditemukan jawaban bahwa, anak muda memiliki persepsi yang bagus tentang eksistensi radio muslim sebagai radio dakwah dalam hal ini radio MQ FM. Mereka menganggap keberadaan radio MQ mampu memberikan informasi tidak hanya tentang keagaamaan tapi juga umum. Mereka selalu mendengarkan radio MQ FM nonstop, sepanjang hari dan malam mengiringi aktivitas keseharian mereka. Sehingga mampu mengubah tindakan mereka menjadi seperti yang mereka selalu dengarkan di radio.Perubahan sikap dan prilaku dari yang sebelumnya tidak begitu mengetahui pengetahuan agama menjadi tahu dan mampu menyebarkannya.

Pendekatan melalui radio ini menjadi langkah yang efektif untuk menyampaikan informasi keagamaan (dakwah) terhadap kelompok anak muda karena acara-acaranya dibuat sesuai segmen dan tidak hanya melulu memberikan informasi keagaamaan akan tetapi juga keilmuan umum yang bermanfaat untuk kehidupan sehari-hari. Selain itu, acara-acara off air yang diselenggarakan juga dapat diterima dengan baik dan menjadi ajang perekat antara radio dan pendengarnya. 


\section{Daftar Pustaka}

Ardianto, Elvinaro \& Erdinaya, Lukiato Komala. Komunikasi Massa. Suatu Pengantar. Simbiosa Rekatama Media. Bandung. 2005

Daymon, Christine \& Holloway, Immy. Metode-metode Riset Kualitatif dalam PR Yogyakarta. 2008

Dominick, Joseph R. The Dynamic of Mass Communications. Media in the Digital Age. $9^{\text {th }}$ ed. McGraw Hill. New York. 2007

Kahmad, Dadang. Sosiologi Agama. Rosda. Bandung. 2002

Kasman, Suf. Jurnalisme Universal. Menelusuri Prinsip-prinsip Dakwah Bil Qalam dalam AL Quran. Khasanah Putera Keilmuan. Jakarta. 2004

Kasmani, Faizal Mohd, dkk. Dakwah Content and Its Method: an Analysis on Islamic Websites.

Littlejohn, Sthephen W. \& Foss, Karen A. Theories of Human Communication. $8^{\text {th }}$ ed. Thomson Wadsworth. Canada. 2005

Littlejohn, Stephen W. Theories of Human communication $5^{\text {th }}$ edition. California. Wadsworth Publishing Company. 1996.

Moleong, Lexy J. Metodologi Penelitian Kualitatif. Bandung. PT Rosda Karya. 2004.

Moustakas, Clark. Phenomenological Research Methods. California. SAGE Publications. 1994.

Muhadjir, Noeng. Metodologi Penelitian Kualitatif. Yogyakarta. Rake Sarasin. 1990.

Mulyana, Deddy. Komunikasi Efektif. Suatu Pendekatan Lintas Budaya. Rosda. Bandung. 2005

Rakhmat, Jalaluddin. Psikologi Komunikasi. Rosdakarya. Bandung. 1994

Ruslan, Rosady. Penelitian Public Relations dan Komunikasi. PT Raja Grafindo. Jakarta. 2004

Saverin, Werner J. \& Tankard, James W, Jr. Communication Theories: Origins, Methods, and Uses in the Mass Media. $5^{\text {th }}$ ed. Longman. US. 2001 